\title{
Examining School Inspectors and Education Directors within the Organisation of School Inspection Policy: Perceptions and Views
}

\author{
Jeffrey Brooks Hall ${ }^{1}$
}

This is an Accepted Manuscript of an article published by Taylor \& Francis in Scandinavian Journal of Educational Research on [date of publication], available online: 10. Feb 2016 http://www.tandfonline.com/10.1080/00313831.2015.1120234

\begin{abstract}
State school inspection creates expectations in the interface between transnational ideas and national policy contexts. However, few Scandinavian studies address how new expectations currently shape the role of school inspectors, relating to national policy frameworks and transnational influences. This article investigates how inspectors and education directors understand and reformulate their regulatory roles through governing schools and local school authorities, in relation to the new framework for school inspection policy in Norway. Using data from the LEX-EL project, semi-structured interviews with three educational directors and six school inspectors in three County Governors' Offices were analysed. The article draws on organizational theory, interpreted within the concept of institutionalization. Findings suggest inspectors function as change agents, experiencing greater dependency through inter- and intra-institutional cooperation than previously. Additionally directors are more tightly coupled to their counterparts in other counties. Moreover, the role of school inspectors is changing, moving from a compliancy-based focus to increased emphasis on selfevaluation and quality assessment.
\end{abstract}

Keywords: School inspection; policy; expectations; institutionalization

\section{Introduction}

School inspection, as one of multiple regulatory tools, is used by state authorities to coordinate and control how school principals and local school authorities comply with legal requirements. On regional, and local levels, inspection processes may furthermore assess the instructional practices of schools, where public inspection reports and media focus might subsequently affect how schools are viewed by the public (Baxter \& Rönnberg, 2014; Rönnberg, Lindgren, \& Segerholm, 2013). Moreover, studies show schools and school

\footnotetext{
${ }^{1}$ Jeffrey Brooks Hall, Department of Teacher Education and School Research, University of Oslo.
} 
principals are vertically scrutinized and thus held accountable in case of deviances from legal and instructional standards (de Wolf \& Janssens, 2007; Ehren \& Visscher, 2006; Lindgren, 2015).

Not only are inspection policy frameworks influenced by national processes of governing, but also through a flow of transnational ideas. Within the European Education Policy Space (EEPS), studies show state school inspectorates in, for example, the Scandinavian countries have drawn from a common pool of ideas (Dale \& Robertson, 2009a; Lawn \& Grek, 2012; Ozga, 2012). However, exactly how these ideas are conveyed and transformed into national contexts varies according to traditions and political systems (Grek, Lawn, Ozga, \& Segerholm, 2013).

The Standing International Conference of School Inspectorates in Europe (SICI), where state inspectoral bodies and networks of actors and experts convene and discuss the role of present and future school inspection policy, is considered to be the driving force of the development of European inspectorates (Lawn \& Grek, 2012). However, to what extent these processes have influenced Norwegian inspection policy is unclear. In any case, studies suggest the Swedish School Inspectorate (SSI) attracts interest from other newcomers in the SICI such as Norway (Grek et al., 2013). This has resulted in work with new frameworks (The Norwegian Directorate for Education and Training, 2013), developed by national inspection authorities aimed at the enactment of a new state inspection policy.

This paper focuses on regular state inspection ("Felles nasjonalt tilsyn"2) in Norway, annually initiated by the Norwegian Directorate for Education and Training (hereafter the Directorate). The study explores how key policy actors, here school inspectors and education directors, are interpreting their mandates and thus how they extend their governing roles in relation to the new framework, with regards to individual and collective beliefs not settled out as an implication for the new framework for school inspection policy. Norwegian inspectoral authorities are undergoing considerable change in their roles as policy executors. Until recently, school inspection policy in Norway has been predominantly compliancy-based ${ }^{3}$

\footnotetext{
${ }^{2}$ Felles nasjonalt tilsyn (FNT) may be translated to Regular State Inspections, and concerns annual inspections initiated by The Directorate.

${ }^{3}$ The Education Act of Norway (Government Act, 1998 Sec. 14-1) states: "The County Governor supervises the municipal and county educational authorities' fulfillment of the duties bestowed upon them." These duties refer to the role schools possess through respecting individual students' rights to e.g. satisfactory education and a healthy and sufficient psycho-social learning environment (Government Act, 1998), and secondly the role County Governors' Offices (CGOs) play by overseeing regulations are followed.
} 
(Hall \& Sivesind, 2014). Nonetheless, it is assumed auditing authorities have been leaning towards their European counterparts (Grek et al., 2013), focusing more on School SelfEvaluation (SSE) and "light touch regulation" (Grek \& Lindgren, 2014).

This paper furthermore enquires into how organizational processes are changing the institutional roles of school inspectors and education directors stemming from perceptions and views (of the parties involved), or rather played out in the state policy arena. Additionally, I emphasize how new expectations are emerging and thus being constructed. . Finally, I argue the informants' perceptions affect future prospects of inspectoral practices, due to changing nationally-based expectations as well as the indirect influence of transnational flows of knowledge (Grek et al., 2013).

Thus, the main purpose of this paper is to investigate current and changing organizational processes of school inspectoral authorities in Norway, seen from the inspectors' and education directors' point of view. Methodologically, this is done through a cross-case comparison $^{4}$ (Dale \& Robertson, 2009b; Manzon, 2007; Ragin \& Amoroso, 2011) based on interview data, supported by legal statutes and policy documents as context for the analysis. Two key points are addressed:

- How the role of the County Governors' Offices (CGOs), as it is perceived by school inspectors and education directors, is changing due to new organizational processes initiated by the new framework for school inspection policy (2014-2017); and

- How the inspectors and education directors understand their contribution to the processes of shaping new expectations towards future inspection practice, as a parameter alongside individual and collective beliefs, values, and norms.

The theoretical scope of this study is two-fold. Drawing first on organizational theory on institutions (DiMaggio \& Powell, 1983; Jennings \& Greenwood, 2003; Pollitt \& Bouckaert, 2004), I explore the perspectives of key actors' about how organizational changes within an institutional framework lead to institutionalization.

Second, this paper is inspired by theoretical frames adhering to organizations more on the micro-level (Czarniawska, 2005, 2008; Eisenberg, Goodall, \& Tretheway, 2010; Scott, 2014; Weick 1979, 2009a). As Czarniawska (2005) pointed out, Weick (1979) turned the

\footnotetext{
${ }^{4}$ The three County Governors' Offices (CGOs) are treated as individual cases; however the data is analysed across cases in order to unveil commonalities and possible differences. I here refer to fourth paragraph p. 9 in this paper for an overview of methods chosen, especially concerning case studies.
} 
attention of organization scholars from institutional structures to organizational processes. Following the rationale of enactment where actors influence upon organizational processes (Weick, 2009a), values, norms, and beliefs are projected onto the future, in the next step forming new expectations (Czarniawska, 2005) operating within and affecting established institutional structures.

The analysis draws on interview data from nine educational officials in three case CGOs in Norway. Across cases, I analyse how school inspectors and education directors contemplate their professional roles and moreover how they cooperate inter- as well as intrainstitutionally. Specifically, this paper examines inter-institutional as well as intrainstitutional dependency and cooperation, and how future prospects and perceptions of the past play a profound role in shaping school inspection policy and practice. In this way, expectations, norms, and beliefs are collectively stretched over multiple actors (Weick, 2001). Thus, this paper contributes both empirically and conceptually to the field of school inspection research, showing how such changes may be analysed through combining new interview data with organizational theory.

First, I present a brief overview of major trends in the field of research on Scandinavian school inspection. Second, I lay out the theoretical-analytical and methodological frameworks. Third, I present the data and analysis. Following the analysis, I finally discuss how school inspectors and directors understand their roles within changing organizational and policy contexts, conclude the overall findings and possible implications of the study.

\section{Research on Scandinavian school inspection}

On the Scandinavian Peninsula, regular, state school inspection takes place in Norway and Sweden. In the Swedish case, recent research has examined how school inspection controls schools (Lindgren, Hult, Segerholm, \& Rönnberg, 2012; Rönnberg, 2011; Rönnberg et al., 2013; Segerholm, 2009), even if the "back stage of school inspection" is characterized by a mix of guidance and uncertainty, requiring inspectors' discretion (Lindgren, 2015). A study by Carlbaum et al. (2014) found school inspection is an influential way of governing education, especially when the SSI was (re-)instated in 2008, growing in momentum ever since (Hall \& Sivesind, 2014; Rönnberg, 2011; Rönnberg et al., 2013; Rönnberg, 2014).

School inspection in Norway is not a new concept, and may be traced back to 1860 when the regional school directors were given the mandate from the Crown to assess the quality of schools. In a Norwegian, historical study of the former regional school directors' 
offices overseeing schools was emphasized as a key task for educational authorities (Mediås, 1996). The regional school directors' offices were however closed in 1992, and via a transitional period from 1992 to 2003, this task was eventually transferred to the CGOs in 2003. From the mid-2000s Regular State Inspections were introduced in Norway. Helgøy and Homme's (2006) comparative investigation of education policy in Norway and Sweden in the 2000s identified several regulatory tools (Helgøy \& Homme, 2006), one being state inspection. Inspection as a governing tool is used to control the legal practices of municipalities and school principals (Helgøy \& Serigstad, 2009). However, it should be noted that these legal practices are prone to legal deliberation and pedagogical interpretation (Sivesind, 2012) .

A recent comparative analysis of White Papers, Green Papers, legal statutes, publically commissioned reports, and state inspection reports (2002-2012) in Norway and Sweden revealed major differences between school inspection regimes of these two countries during the 2000s (Hall \& Sivesind, 2014). Secondly, the study demonstrated that school inspection policy in Norway until recently has focused on compliancy-oriented "modes of governing", while also projecting modes more adhering to evaluation.

Finally, school inspection policy in Norway is currently undergoing eminent policy reform towards inspection based more on SSE (The Norwegian Directorate for Education and Training, 2013).This change suggests Norway is slowly closing in on its neighbours regarding school inspection policy and practice (Grek et al., 2013; Hall \& Sivesind, 2014). Thus, I suggest Norwegian authorities have leaned towards other countries, possibly the Scottish and Swedish systems (Grek et al., 2013; Lawn \& Grek, 2012). Bearing these studies in mind, this paper furthermore contributes to the field by examining how legal statutes, new steering documents, and guidelines are reflected in the way in which school inspection is perceived by school inspectors and education directors responsible for carrying out state goals.

In the following section, I outline the analytical framework, drawing from organizational theory focusing on expectations, enactment, and institutionalization, aiming at illuminating ongoing changes and processes within the three CGOs in the study.

\section{Analytical framework}

In this section, I present the analytical framework, to understand how school inspectors and education directors contemplate current and undergoing institutional change, and secondly how these actors enact upon changes which have implications for institutionalization processes within the CGOs. 


\section{Expectations and institutional change}

In an ideal, bureaucratic world, decision-making in the public sector is funnelled by rationality, steered by formalized, legitimized rules (Brunsson \& Olsen, 1998). However, new institutionalists have struggled with grasping how individual actors, within collective bodies, create social worlds that shape action through normative, legitimated rules (Jennings \& Greenwood, 2003). These rules form the individual and collective actions as well as structures of institutions, through regulative, normative, and cultural-cognitive elements (Scott, 2014).

The analysis is first influenced by literature which takes an institutional approach to organizations (Boxenbaum \& Strandgaard Pedersen, 2009; DiMaggio \& Powell, 1983; Jennings \& Greenwood, 2003; Meyer \& Rowan, 1977; Pollitt \& Bouckaert, 2004; Scott, 2014). In this paper, institutions refer to "regulative, normative and cultural-cognitive elements that, together with associated activities and resources, provide stability and meaning to social life" (Scott, 2014, p. 56).

Theorists such as DiMaggio and Powell (1983) modified early explanations by, for example, Parsons (2012) of how institutions shape and change the social context of organizations (Brunsson \& Olsen, 1998; Jennings \& Greenwood, 2003). Through such change, new structures are created, potentially "rocking" the institutional pillars which frame these organizations. Finally, social change does not emerge in a vacuum, but "challenges, borrows and to some extent displaces previous institutions, inheriting certain beliefs, norms and organizational traits" (Scott, 2014, p. 114). A question is how the institutional bricolage of the CGOs is changing, thus adapting to both old and new expectations.

According to Scott (2014), indicators of regulation may be rules, laws, and sanctions (Scott, 2014). In this sense, policy regulation refers to rules and regulations as well as to certain expectations of legal compliancy. Following this argument, legal deviations may lead to certain sanctions, as part of the government's "stick" (Bemelmans-Videc, Rist, \& Vedung, 2007).

Finally, school inspectors, both individually and collectively, may be considered as institutional agents, however differing in the way they wish to employ the regulative, normative, and cognitive tools in their efforts to construct the very institution in which they manoeuvre (Scott, 2014). Thus, a central question to be approached is how school inspectors and education directors in Norway understand how they, as key actors, are contributing to change in future inspectoral policy and practice. 


\section{Enactment and institutionalization}

School inspectors are allowed considerable professional discretion thus exercising judgment in their everyday tasks (Lindgren, 2015; Sowada \& Dedering, 2014), even though decisions are regulated according to rigid legal structures and norms. This paper argues that school inspectors and education directors, in addition to being change agents, act as field-level institutional entrepreneurs, creating change or influencing rules, norms, and belief systems from within (Hardy \& Maguire, 2008).

Institutions in this paper are furthermore considered to be socially constructed entities, not solely shaped by normative structures, but created by individual and collective actions within loosely-coupled organizations (Berger \& Luckmann, 1967; Boxenbaum \& Strandgaard Pedersen, 2009; Thornton \& Oscasio, 2008). Thus, within these loosely-coupled structures, key policy actors such as school inspectors are themselves reshaping their organizational contexts.

In the Scandinavian institutional tradition, Boxenbaum and Strandgaard Pedersen (2009) defined loose coupling as "the ability of actors to couple and decouple organizational elements and activities, whether unintentionally or as they see fit in a particular situation" (Boxenbaum \& Strandgaard Pedersen, 2009, p. 189). Moreover, within such processes, "actors constantly construct organizations through their actions and their interpretations of what they themselves and the other are doing" (Czarniawska, 2008, p. 7).

Thus, institutionalization concerns processes that both order and constrain, but might also enable various forms of interaction and organization (Cooper, Ezzamel, \& Willmott, 2008). Furthermore, institutionalization in this paper refers more precisely to:

Certain processes happening to an organization over time, reflecting the organization's own distinctive history, the people who have been in it, the groups it embodies and the vested interests they have created, and the way it has adapted to its environment. (Selznick, 1957, as cited in Scott, 2014, p. 24)

According to Scott (2014) changes in institutions result from deliberative processes which are enacted into a set of codified rules (Scott, 2014, p. 163). Taking on a cultural-cognitive approach to institutionalization, actors are understood as creators of new institutional frameworks (Scott, 2014). The thought of actors actively taking part in the shaping of their organizational frameworks brings us towards the concept of "enactment" (Weick, 1979, 2009b). Following these viewpoints, CGOs are not "stagnant" entities, but rather constantly 
changing bodies, prone to influence not only from the outside, but also resulting from readjustments to inter- and intra-organizational processes.

In view of the analytical framework presented above, I have put forth the idea that school inspectors and education directors are actively contributing to the development of new professional roles as enforcers of state policy. By focusing on the conceptual framework outlined, this paper generates new insight of how organizational processes may take place both individually and collectively, both within and across existing institutional frameworks.

\section{The study and its methodology}

This study is grounded in a larger study ${ }^{5}$ of multilevel actors within compulsory and uppersecondary education in Norway. Through reading the interview data as primary data, certain images appear of how school inspection is perceived and projected. In order to construct these images, researchers connect different parts of the things they study in order to create more complete portraits based on some idea of how these parts are or may be connected (Ragin \& Amoroso, 2011).

In this paper, interviews with six school inspectors and three education directors serve as the primary data source, supported by legal statutes and policy documents as contextual information. The excerpts from the interview material have been selected to illustrate typical traits of the whole dataset. Each interview was conducted by the project team on site at the CGOs, lasting from 60 to 90 minutes. All interviews were with individual informants, except one $^{6}$. A common interview guide was used, even though a semi-open method was chosen (Kvale \& Brinkmann, 2009). Finally, the interview guide addressed five areas: a) the aim of state inspections, b) steering and organizing state inspections, c) inspection process and methods, d) assessment of background documentation and inspectors' and directors' competency, and e) inspection and organizational development.

Following data collection, extensive post-interview discussions took place in the project team, ensuring communicative validity (Grønmo, 2004). All interviews were transcribed and uploaded in NVivo10 for analysis, enabling a cross-case comparison of transcriptions.

\footnotetext{
${ }^{5}$ Legal Standards and Professional Judgment in Education Leadership (LEX-EL) is a four-year research project supported by the Research Council of Norway (RCN). http://www.uv.uio.no/ils/english/research/projects/legalstandardsedu/

${ }^{6}$ The interview with Patricia (CGOEE) and Eva (CGOEL) at CGO "East" was conducted as a group interview.
} 
In a comparative approach, researchers enquire into how the different parts of each case, in this study the three CGOs, are linked and then attempt to make sense of each case (Ragin \& Amoroso, 2011). Manzon (2007) referred to the known model by Bray and Thomas (1995) and outlined how a researcher may proceed in comparing places as well as spaces, the latter referring, for example, to inter-institutional processes and interaction. Thus, I compared the three CGOs to find commonalities (Steiner-Khamsi, 2002) in how the informants perceive school inspection policy in general, and specifically how these institutions seem to be currently undergoing eminent change.

To sum up, this study offers a cross-case comparison study of diversity within a given set of cases (Ragin \& Amoroso, 2011), inspired by a specified analytical framework. Before presenting the analysis of the interview data, the next section offers a brief overview of the informants, their main duties, and the three cases (see Table I).

\section{Overview of CGOs' duties and informants}

In Norway, there are $18^{7}$ CGOs representing the central Norwegian government. The CGOs are responsible for carrying out the intentions, goals, and regulations expressed by the Parliament and Ministry of Education, for example through school inspection. As part of the inspection process, SSE as a key tool in the new inspectoral handbook has increasing importance, functioning as a basis for developing interview guides and student surveys, aimed at specified focus points such as special education, or student learning outcomes. As shown in several studies, SSE is a central feature of the data which inspectors use in assessing schools (Grek et al., 2013). However, classroom observations are not a part of the inspection process in Norway, as opposed to, for example, the Swedish system (Lindgren, 2015).

Interviews in this paper are with key actors, either trained educators or lawyers, in three case CGOs: County "West," County "North," and County "East." Each of the CGOs consists of seven to nine departments, one of them the Education Department, led by a Director of Education (DE) and a Deputy Director (DDE). Table I offers a brief overview of the three cases and the nine informants:

\section{[Table I about here]}

\footnotetext{
${ }^{7}$ There are in total 18 CGOs in Norway, as the counties of Oslo and Akershus have one common County Governor.
} 
In sum, through exploring the interview data, I investigate how school inspectors and education directors view interaction with other governmental institutions, how intrainstitutional processes and change takes place, and which expectations the interviewees experience in their everyday work as "auditors" (Power, 1997). Finally, I pinpoint which direction the CGO officials' roles are moving in the future, due to new expectations in addition to a possible adjustment to the ongoing processes of Europeanization (Grek et al., 2013; Hall \& Sivesind, 2014; Lawn \& Grek, 2012).

\section{Data analysis: Inspection as seen from the inspectors' and education directors' point of view}

\section{Institutional processes, change, and the creation of new expectations}

Institutional change is not only due to adjustments to new expectations (Czarniawska, 2005; Scott, 2014) but also as a result of internal processes becoming legitimized through use of rules. (Jennings \& Greenwood, 2003).

School inspection policy in Norway is currently undergoing change (Hall \& Sivesind, 2014), due to new expectations emerging within and between institutional structures. First, the CGO inspectors reported they are more welcomed at schools than before, through both supportiveness and controlling legal compliancy. Previously, the school inspectors felt they lacked sufficient legitimacy. Eva, a lawyer at CGO "East," expressed this when asked about change:

We think now, that we are welcomed differently, that we can offer something at the same time we are out there, and can help to a greater extent than we did previously, and I mean that it is directly linked to the teaching that the students receive. I absolutely think so. (Eva, CGOEL)

Second, the mandate of the CGO is clearer, even if there are substantial differences within the individual CGOs. When asked if there has been change in the CGOs' mandate, Paul at CGO "East" said:

The mandate has become much clearer. At the beginning it was more up to ourselves how we managed to handle the school inspections itself. In that way, yes, the mandate has become much clearer. (Paul, CGOEDE) 
On the other hand, one of Paul's inspectors had a different approach to the same question:

No, not in the mandate, you can say - well, the mandate has all the time been through the Education Act through the letter of delegation, you can say. About carrying out inspection on behalf of the Ministry of Education. (Patricia, CGOEE)

Internally, the inspection teams work under a high level of autonomy, even if eventually their work is scrutinized by their leaders.. All three directors, pointed out: "Yes, we have to check what's being published and sent out, but we do trust them to do their jobs." On one hand, they must control that reports are up-to-standards; however they trust their inspectors to execute their jobs in a timely manner:

Well, I must say that I am impressed by the amount of work they [the inspectors] put into the inspections. They write the report together, the inspection teams. I think they chew on every single word. And I am sure they use a lot of time to ensure that what they do is of high quality. Then things are like this: I sign all documents which leave this office, so I read through. (Harald, CGOWDE)

Not only are the CGOs currently undergoing predominant change, but there exist certain "binding expectations" (Czarniawska, 2005; Scott, 2014) dictating how actors can exercise their daily tasks, internally as well as externally. These expectations are specifically linked to two areas: the role of the media, and pressure from the Directorate.

The media plays a considerable role in shaping the view of schools and school inspection (Baxter \& Rönnberg, 2014; Rönnberg et al., 2013). The local media is, according to the informants in this study, interested in high-profile cases, especially through complaint cases. These cases, as well as risk calculation, serve as platforms for carrying out self-initiated inspection, being a substantial part of their overall inspection portfolio:

The press has access to postal journals and can access what they want, what parents wish to do, well, there are parents who say: "Now we are going to the press." (Heidi, CGONE) 
Heidi also added the local newspapers were an important source of information, following up on individual cases which have emerged in the media.

Finally, the Directorate is clearly an important factor in imposing new expectations upon its "subordinates." The Directorate develops inspection handbooks, holds courses for the CGO inspection departments, thus shaping the institutional boundaries in which these can navigate. One of the educators, Heidi, said this about expectations "from above":

We do, I was about to say, receive our "activity demands" from the Directorate. Regarding how many inspections we should have carried out in a year, and there are supposed to be some regular state inspections [FNTs]. So it is the Directorate which steers this for us. And it is they who produce the instructions and in a way tell us what we are supposed to be looking for. (Heidi, CGONE)

However, there seemingly exists leeway in the way the CGOs can manoeuvre within a tighter regulatory framework, especially through, "self-initiated inspections" making up $40 \%$ of the total inspection portfolio. Sophie said this about how the CGOs may manoeuvre within the framework:

But these instructions, it does mean there is quite a tight regime. [...] Then you have to find and form that leeway without breaking instructions, and without surpassing what is understood as clear guidelines. [...] Trying to find that leeway is not always easy, because you are supposed to be loyal towards the guidelines. But the possible leeway you have, might be as easy as just changing the wording. (Sophie, CGOWE)

As seen above, actors experience some level of leeway in carrying out their tasks, however not without certain expectations from the media not to mention key policymakers in the Directorate. Additionally, there seems to be a much clearer role definition of the CGOs, more tightly coupled (still loosely) to the Directorate than previously through inter-institutional liaisons.

\section{Inter-institutional dependency and cooperation}

Organizations are regarded to exist in complex and relatively unstable environments (Eisenberg et al., 2010). However, within stable institutional frameworks, enactment is visible in these emerging organizational structures (Weick, 2009a). Here individuals interact across 
formal borders engaging in meaning-seeking within an inter-institutional system (Thornton \& Oscasio, 2008).

In their relation to the Directorate, the inspectors and directors are now more an equal party. The participants expressed more interaction than previously with their superiors, the Directorate. Sophie, at CGO "West," said this when asked about the link between the two institutions:

Before, there was more of a one-way communication. Now, there is an actual dialogue. When I started, the Directorate and especially their inspection department was new too. So it could be that they were a bit careful at first as well, and were a bit insecure about their own role, and how much they were allowed to do. (Sophie, CGOWE)

Harald, the CGO Education Director at CGO "West," commented on the improved relationship between the two institutions:

I cannot say much about the division of labour between the Ministry and the Directorate, because I do not know much about it. But in any case, concerning the division of labour between the Directorate and the CGOs, the cooperation is very good. I do not think it was always like that. Because I hear it from those who have been here longer - that it is a new way of working, and a whole new attitude towards our input. (Harald, CGOWDE)

Heidi at CGO "North," also reported on greater openness in their relationship towards the Directorate, especially concerning recent piloting of the new inspection handbook (The Norwegian Directorate for Education and Training, 2013):

The rounds of piloting [referring to the new inspection handbook] show that the Directorate has been very cooperative and "all ears." Yes, so all honour to the inspection department at the Directorate. (Heidi, CGONE)

A question which arises is if the relationship between the Directorate and the individual CGOs possibly involves more direct steering than previously, even if the CGO officers do feel they are "heard more", suggesting they are seemingly not critical towards the fact they are now more steered by their central supervisors. Thus, through cultural-cognitive processes 
and institutional interaction, where mutual norms and ideas evolve, there are clear expectations of how the normative, institutional roles should be filled.

These cognitive processes may lead to organizational interaction across levels (Scott, 2014), where exchange of ideas becomes a basis for new conceptions and beliefs of the role of future school inspection. One example of clear expectations from the Directorate is through annual reporting from the individual CGOs, compiled into state reports. Informants were asked about how they exchange experience and professional judgment during the process. Christian, a lawyer from CGO "West," said this about the previous annual reporting:

We have to report annually on the inspections which we have carried out. There were a lot of legal deviances ... and on a very detailed level ... so they maybe did not give a realistic picture of the schools and municipalities which had had been inspected. And it is a bit strange to compare the different municipalities, and they had "x" number of legal offences, and the others had this much. At the same time conditions at the school with the most legal offences could be very good, even if they lacked a lot of routines. (Christian, CGOWL)

Christian expressed concern about the previous summative "counting system", focusing on counting legal deviances and offences, and asserted that the system did not accurately report on what actually took place in each inspection site.

Negotiation and enactment across professions and levels as well as within organizations takes place, possibly resulting in institutionalization processes (Scott, 2014). As the analysis shows, school inspectors largely negotiate how inspections are to be carried out, in which a new model may be emerging in lieu of the new inspection handbook (The Norwegian Directorate for Education and Training, 2013). These movements also seem to be taking place through intra-institutional cooperation between the Directorate and the CGOs, where actors enact and contribute to the shaping of their common future. The Directorate clearly functions as a pivoting centre of this interaction. Drawing on Scott (2014), this perspective "allows us to view social interaction, social ties, communication and conversation not merely as expressions of structure, rationality, consciousness and culture, but as active sites of creation and change" (Scott, 2014, p. 174).

Networks between actors facilitate relationships, and inspection policy is discussed and even negotiated upon. It should be added that these networks are more on the CGO director level, than the individual inspector level. Accordingly, there exists well-developed 
inter-institutional cooperation between CGO Education Directors, which Harald from CGO "East" reported on:

We take part in a five-county cooperation. We have regular meetings, the CGO Education Directors, and then we have seminars with our employees where we talk about inspection. (Harald, CGOWDE)

Thus, inter-institutional cooperation and dependency, based on the informants' viewpoints, plays a substantial part of the roles of CGO inspectors, and especially the directors. These networks seem to add to their professional development, not only between different CGO offices, but even more so through on-the-job training held by the Directorate. Subsequently, as argued above, they may however be directly influenced by the views, norms, and expectations set by the central government.

\section{Intra-institutional dependency and cooperation}

There is reason to claim that organizing is accomplished through not only formal talks and meetings, but through informal talk in the hallways and on the move between official venues (Czarniawska, 2008).

Analysis shows the CGOs are not only collaborating inter-institutionally.

Organizations are places where a high level of intra-institutional cooperation on different levels takes place, relating to the formal and informal structures within the organization. Interview data shows there are certain formal structures within the CGOs, shaping how organization functions on a daily basis. On the other hand, informants report on informal structures being equally important, such as patterns of behaviour, work routines, informal meetings, informal chats, and divisions of work:

We try to learn from each other. So for example we had a course which lasted a couple of days where we kind of selected some who had long experience with inspection to go through the inspection handbook and so on. Well, with all of us in the department, independent of if they were new or old. Because I at least experience that even those who have been here for ages don't always have the framework under their skin. [...] So that everyone should get a feeling of ownership to the handbook. (Harald, CGOWDE) 
Informal meeting places (Czarniawska, 2008) are also a predominant trait of the CGOs' cooperative structure, especially on the inspection team level. The inspection teams are not stagnant throughout the work year, rotating after each round of inspection. They divide work between members of the inspection teams, investigate findings, and then collaborate on the final report. As Sophie from CGO "West" said: "We don't sit and write word by word in a group. We divide it like 'you take part one, I'll take part two and you part three', and then we make a draft." Moreover, collaboration also takes place not only on-site and in the office, but more informally. Sophie added:

When we have done the interviews [on site] then we can hopefully sort out, so we can land the thing, so then we quite shortly after the interview, often the following day, often in the car on the way home from an inspection, even if we don't write it all down in the car: a summary; what do we now know? Have we landed here? There we were clearly a "yes," why are we over on a "no" now? Right, it does happen now and then, doesn’t it? So, summing up is extremely important. (Sophie, CGOWE)

This is an example of the (re)development of institutional structures, even if some of the processes seem a "sublime" part of the formal "pillars." A vital part of the intra-institutional collaboration is the professional interaction between the two predominant professions in the CGO inspection departments; the lawyers and the educators. The existence of a high degree of mutual respect, trust, and understanding between the two professions, each acknowledging the other's strengths and possible weaknesses, seems clear. All informants agreed a combination of the two is necessary to carry out the duties bestowed upon them:

The interaction between the lawyers and the educators is important. When you are now going to go in and look at student assessment [referring to the new state inspection handbook, 2014-2017], you have to have experience from school to understand the jargon. Of course, lawyers also understand this; it's not like that. But to get the whole picture, with the law on one side and pedagogy on the other, you have to have both. (Heidi, CGONE)

Heidi's colleague Jens, a lawyer, also reported on how the two professions complement each other: 
Well, I think that we complement each other very well when it works out as well as it does. So it could be that sometimes ... if the educator wants to be the lawyer and the opposite, it may quickly be like ... a challenge, but if everyone uses their role a bit consciously, then I think it can turn out well. We do have economists which we need sometimes. But I think we mostly complement each other, yes. But with an increase in inspections, then it's clear that educators have to almost be kind of "hobby lawyers." So they quickly become influenced by our way of thinking, which maybe is a bit opposed to their pedagogical hearts. (Jens, CGONL)

Even if the informants reported on an apparent consensus between the main two professions in question, some findings suggested the existence of a judicial "tug-of-war." When asked if there were any difficult decisions concerning reporting, the Education Director of CGO "East" explained:

No, not any concrete examples of difficult decisions, but it may be about: Do they [the schools] follow the legal demands? And here lawyers and educators can disagree sometimes. That is one thing, us coming from education you know, then we do like we always have done (laughing). And [we] find very good reasons for it being like this [...] and then a lawyer can come and say, "Yes, but the law says this." But it has to adapt to reality, what's the reason, what lies behind, why did that rule appear? (Ruth, CGONDDE)

Based on the interview data, negotiation plays a central role in the everyday work carried out by the CGOs, however more internally and in conjunction with their interaction with the Directorate, than in the interplay between school principals, local school authorities, and school inspectors. Negotiation is in the end a central part of all organizational development (Boxenbaum \& Strandgaard Pedersen, 2009).

In short, intra-institutional cooperation in the three CGOs is widespread, and takes place both formally as well in more informal settings (Czarniawska, 2008). Additionally, negotiation is an important part of the everyday work of the inspectors and education directors. In the following section, I present how the CGO professionals understand the past, present, and future of school inspection. 


\section{Perceptions and prospects of former, present, and future school inspection}

As the excerpts above suggest, the CGOs are still changing and adapting to a new institutional role, more tightly coupled to the Directorate. However, that has not always been the case.

Formerly, the informants reported on a certain distance from the CGOs to the Directorate, where they felt they did not have the same level of influence as in the current situation. Additionally, schools were previously more ambivalent towards the CGO inspectors, as Patricia at CGO "East" explained: "Before, when the CGO came, it was like getting a visit from the devil. But now, they [the schools] receive help and advice." The inspectors who have experienced both the "old" and the "new" systems reported more interaction with schools and local school authorities now:

Coming out in municipalities and schools and interviewing people, it has been new for me. And I do see that it is a matter of practice, and I now feel much more secure that I did during the first rounds [of inspection]. Now it is easier to have a dialogue, and not be so obsessed about those questions and the themes you are supposed to get through. (Christian, CGOWL)

Thus, there is currently more emphasis on support, not only control, and as Harald (CGOWDE) said: "All the employees here are very satisfied that there is now a totally different focus on the fact that giving advice is one of our primary functions, in addition to finding legal deviances.” Moreover, increasing focus on the inner lives of schools has resulted in compiling inspection reports differently than before:

We now also write up reports in a different way than before, so we surely describe more that practice of the municipalities now, than we used to. Not only concluding with legal deviances and notes. And observations ${ }^{8}$ which support them. But now we have a different method of inspection which makes us describe even more, and explain why it is within [the law]. (Jens, CGONL)

The balance between control and support is however not without challenges, especially during the first years of regular state inspections which commenced during the mid-2000s:

\footnotetext{
${ }^{8}$ These do not refer to classroom observations, which are not a part of the inspection process in Norway. The informant here (Jens, CGONL) referred to observations during interviews with school leaders, teachers, etc.
} 
With the method we started out using in 2006, we were very concerned about which hat we were wearing - if it was the "inspectoral hat" or the "advisory hat." And it was actually wrong to bring an "advisory hat" with us out on inspection, because it wasn't supposed to be like that. We are very careful not to mix roles. (Eva, CGOEL)

Nevertheless, there is all reason to point out the inspectors do not take lightly their current roles as both regulators and advisors, roles which seemingly will become more differentiated in the future:

When you are standing in front of a municipality and saying they have broken Norwegian law, then ... well, then, you have to be sure when you say that to people. So it is clear that it is really lodged in the spines of many of us. And it should be right there. Because you have to have a certain humbleness, and at the same time show them respect as well. (Christian, CGOWL)

From a leadership point of view, seen through the eyes of the CGO Education Directors, the tasks carried out by the inspection teams are highly valued. One of the directors, Harald, said this about how he perceives the current role of his teams:

In my view, I experience that the inspection teams to a great extent agree upon their decisions. I think they are strict. Well, now, I am trying to be honest here. And I hope that's what we are supposed to be (laughing). Strict, because we are strict. And we express when we feel that things are breaking the law, and then we have to tell them. And, just to have said it, sometimes it is almost impossible to be able to be within the law. Because the demands are so high. (Harald, CGOWDE)

The new school inspection handbook (The Norwegian Directorate for Education and Training, 2013) is currently changing the way the inspectoral process is executed. This handbook, which was piloted in 2012-2014 in several counties and is now nationally implemented, implies predominant change for not only the CGOs, but also schools, school principals, and municipalities. The role of the inspectorate is subsequently changing into a more supportive one, not only controlling legal compliancy, but offering more advice. This was viewed positively by the informants: 
There is now a totally different approach, undoubtedly. And what's now coming, right, well it's constantly developing, is more into the "advisory modus," I was about to say, where we go out with advice prior to inspections, and as well afterwards when closing the case. (Paul, CGOEDE)

Finally, barely mentioned by the informants, is the question of whether the CGOs have adequate capacity to take on these new expectations. The CGOs are increasingly in the process of hiring lawyers, and not only educators and economists, possibly due to a greater juridification of the educational sector. However, the possibility of them on taking new tasks and extending their "regulative arm," seemingly without sufficient new recruitment of staff to carry out these new obligations, may turn out to be a weightier challenge than expected in the future.

\section{Discussion}

The aim of the study was to investigate how school inspectors perceive their roles as policy "enactors" in a sphere where new expectations are emerging, and where future prospects are somewhat unsettled. Thus, in many ways, it has been a question of studying a "moving target," where the goalposts are constantly changing their location.

Through combining a new dataset with organizational theory, the analysis has first demonstrated that the CGOs are characterized by informal meeting places and negotiation between professions as well as formal routines and institutional structures. However, a sharp distinction should be made between the formal structure of an organization and its actual dayto-day work activities (Czarniawska, 2008; Meyer \& Rowan, 1977). Thus, there is reason to point out that the informants' impressions of their work day stem from both "front-office" tasks such as onsite inspection, but also "back-office" activities such as staff meetings and completion of inspection reports.

Second, Bemelmans-Videc et al. (2007) discussed a "judicial give-and-take" process building on legitimacy, where not only repressive orders are given and legal control is executed, but "agreements" based on deliberation and judgment are also included. Thus, deliberation is argued to be a common trait of school inspection in Norway, supported by other international studies (Lindgren, 2015; Sowada \& Dedering, 2014). The inspection process is characterized by negotiative processes where mutual understanding of the law is deliberated through legitimacy and control. Within the institutional, structural boundaries 
these policy enactors experience it to be challenging to navigate in a rigid, new policy framework for state school inspection. Thus, there lies within the law, to some extent, legal leeway from within which actors can manoeuvre.

Moreover, school inspectors and directors are in a professional sense held accountable to their legal actions and decision-making, not the least through carrying out state school inspections. There are clear expectations both internally and externally concerning to what extent the inspectors and the directors are bounded to act in compliance not only to written law, but also informal norms and "rules of the game." Not only are inspectors and directors held externally accountable by the Directorate, but internally through weekly meetings and the processing and publication of inspection reports on the CGO websites. Additionally, the media seems to play a relevant role, at least on the local level. This coincides with studies of Swedish school inspection and the role of local newspapers (Rönnberg et al., 2013).

Fourth, another interesting feature of the CGOs is the importance of trust in the relations between the directors and inspectors, where the inspectors possess not only legal headroom, but "professional leeway" in their everyday work, however prone to certain accountability mechanisms. This concurs with previous broad studies focusing on the important role of trust in educational systems (Bryck \& Schneider, 2002; Tschannen-Moran, 2004).

Fifth, informants reported on profound change in the way they collaborate with other governmental bodies such as the Directorate, especially through the development of the new inspection handbook (The Norwegian Directorate for Training and Education, 2013). As shown in other Scandinavian studies, the detailed use of rigid inspection handbooks including templates has led to greater detailed guidance of inspectors' work, interfering in their professional judgment (Lindgren, 2015). The previous relationship between the CGOs and the Directorate was characterized by what may be called a top-down approach to policy development and implementation, where limited interaction took place. In the current inspectoral system, the CGOs and the Directorate have collaborated in developing what will be the new system of school inspections. However, as pointed out by Lindgren (2015), this may imply more direct steering of the CGOs than previously.

Finally, the main finding of this study is the role of inspectors is transforming, from a predominantly control-based inspection to a greater focus on intervention, advice, and quality assessment, where each individual school's pedagogical praxis will be scrutinized. To sum up this point, I would like to quote one of the educators at CGO "North": 
The greatest challenge is to get municipalities to understand that we are not trying to catch them with their pants down; we are aiming at helping them keep their pants up! (Heidi, CGONE)

Thus, based on the data at hand, I argue that enabling schools to contemplate how the newly refreshed "light touch" (Grek \& Lindgren, 2014) and supportive approach of the CGOs is still to be tested and implies a more cooperative climate than previously. The new inspection handbook (The Norwegian Directorate for Education and Training, 2013) signals more interventive aspects, scrutinizing the assessment practices of compulsory and upper-secondary schools. In this sense, inspection as a regulatory tool is changing, not only controlling legal compliancy but also now monitoring the assessment practices of individual schools. If this is the case, school inspection in Norway is currently developing more in the direction of other European inspectoral systems (Grek et al., 2013; Hall \& Sivesind, 2014). An underlying question is if the new inspectoral regime has resulted in more leeway for schools and local school authorities. In this sense, less direct control does not mean limited control, but implies new expectations and new forms of indirect control, potentially aiming at steering the inner lives of schools. Consequently, this may imply a move from a monitoring and reporting mode, to one more acclimated to the development and support of schools and local authorities (Lawn \& Grek, 2012), even if this may imply more indirect steering.

In sum, this paper contributes both conceptually as well as empirically to the field by suggesting school inspectors function as institutional "agents" and "entrepreneurs" (Hardy \& Maguire, 2008; Scott, 2014), enacting and thereby actively shaping the future institutional role of the Norwegian CGOs. Comparing the three cases shows few distinct differences across CGO "North," "West," and "East," however more so between the nine informants.

Additionally, there are clear contrasts between how the lawyers, educators, and economists conceive and portray their roles as executers and "agents" of the inspectoral "regime" and policy within which they operate. The concept of agency refers to an actor's ability to have some effect on the social world; alerting to rules, relational ties, or distribution of resources, supporting a more interactive and reciprocal view of institutional processes (Scott, 2014). How these actors and institutions in the educational sector will respond to future expectations is yet to be seen, and can only be unravelled through additional empirical investigations of the state school inspection bodies and the "auditees" (Power, 1997). Thus, this implies that future research on school inspection authorities, through conceptualization, carrying out fieldwork, and analysing data, has to delve deeper into how key actors within inspectoral bodies are 
themselves changing the organizational structures from within as well as through external collaboration.

\section{Acknowledgments}

This work is supported by the Research Council of Norway (RCN) in full. The author wishes to acknowledge the Research Council of Norway for financing the project "Legal Standards and Professional Judgment in Educational Leadership" (LEX-EL), based at the University of Oslo, Norway. Finally, the author wishes to thank colleagues at the Faculty of Educational Sciences for their valuable comments.

\section{Note on contributor}

Jeffrey Brooks Hall is a PhD research fellow at the Department of Teacher Education and School Research, University of Oslo, Norway. He is currently working on a comparative study of state school inspection in Norway and Sweden, as part of the research project: Legal Standards and Professional Judgment in Educational Leadership (LEX-EL).

\section{References}

Baxter, J., \& Rönnberg, L. (2014). Inspection and the media, the media and inspection. In S. Grek \& J. Lindgren (Eds.), Governing by inspection (pp. 159-172). London: Routledge.

Bemelmans-Videc, M. L., Rist, R. C., \& Vedung, E. (Eds.). (2007). Carrots, sticks \& sermons: Policy instruments \& their evaluation. New Brunswick, NJ: Transaction Publishers.

Berger, P., \& Luckmann, T. (1967). The social construction of reality - A treatise in the sociology of knowledge. New York, NY: Doubleday Anchor.

Boxenbaum, E., \& Strandgaard Pedersen, J. S. (2009). Scandinavian institutionalism - A case of institutional work. In T. B. Lawrence, R. Suddaby, \& B. Leca (Eds.), Institutional work - Actors and agency in institutional studies of organizations (pp. 178-204). Cambridge: Cambridge University Press.

Bray, M. \& Thomas, R. M. (1995). Levels of comparison in educational studies: Different insights from different literatures and the value of multilevel analyses. Harvard Educational Review, 65(3), 472-491. 
Brunsson, N., \& Olsen, J. P. (Eds.). (1998). Organizing organizations. Bergen: Fagbokforlaget.

Bryck, A. S., \& Schneider, B. L. (2002). Trust in schools: A core resource for improvement. New York, NY: Russell Sage Foundation.

Carlbaum, S., Hult, A., Lindgren, J., Novak, J., Rönnberg, L., \& Segerholm, C. (2014). Skolinspektion som styrning [School inspection as governing]. Utbildning \& Demokrati, 23(1), 5-20.

Cooper, D. J., Ezzamel, M., \& Willmott, H. (2008). Examining “institutionalization": A critical theoretic perspective. In R. Greenwood et al. (Eds.), The Sage handbook of organizational institutionalism (pp. 673-701). Thousand Oaks, CA: Sage.

Czarniawska, B. (2005). Karl Weick: Concepts, style and reflection. The Editorial Board of the Sociological Review, 53 (Issue Supplement s1), 267-278.

Czarniawska, B. (2008). A theory of organizing. Cheltenham: Edward Elgar Publishing.

Dale, R., \& Robertson, S. (Eds.). (2009a). Globalisation and Europeanisation in education. Oxford: Symposium Books.

Dale, R., \& Robertson, S. (2009b). Beyond methodological "ISMS" in comparative education in an era of globalisation. In R. Cowen \& A. Kazamias (Eds.), International handbook of comparative education (pp. 1113-1127). Dordrecht: Springer.

DiMaggio, P. J., \& Powell, W. W. (1983). The iron cage revisited: Institutional isomorphism and collective rationality in organizational fields. American Sociological Review, 48(2), 147-160.

Ehren, M. C. M. \& Visscher, A. J. (2006). Towards a Theory on the Impact of School Inspections. British Journal of Educational Studies 54 (1), 51-72.

Eisenberg, E. M., Goodall, H. L., Jr., \& Tretheway, A. (2010). Organizational communication - Balancing creativity and constraint (6th ed.). Boston, MA: Beford/St. Martin.

Government Act. (1998). Act relating to primary and secondary education ('Opplæringsloven'). Retrieved from http://www.regjeringen.no/upload/KD/Vedlegg /Grunnskole/Education_Act_Norway_30_September_2010.pdf

Grek, S., Lawn, M., Ozga, J., \& Segerholm, C. (2013). Governing by inspection? European inspectorates and the creation of a European education policy space. Comparative Education, 49(4), 486-502.

Grek, S., \& Lindgren, J. (Eds.). (2014). Governing by inspection. Oxon: Routledge.

Grønmo, S. (2004). Samfunnsvitenskapelige metoder [Methods in social science]. Bergen: Fagbokforlaget. 
Hall, J., \& Sivesind, K. (2014). State school inspection policy in Norway and Sweden (20022012): A reconfiguration of governing modes?. Journal of Education Policy, doi 10.1080/02680939.2014.945488.

Hardy, C., \& Maguire, C. (2008). Institutional entrepreneurship. In R. Greenwood et al. (Eds.), The Sage handbook of organizational institutionalism (pp. 198-217). Thousand Oaks, CA: Sage.

Helgøy, I., \& Homme, A. (2006). Policy tools and institutional change: Comparing education policies in Norway, Sweden and England. Journal of Public Policy, 26(02), 141-165.

Helgøy, I., \& Serigstad, S. (2009). Tilsyn som styringsform i forholdet mellom staten og kommunene [Supervision as a governing tool in the relationship between the state and the municipalities] (Vol. IX). University of Bergen: Stein Rokkan Center.

Jennings, P. D., \& Greenwood, R. (2003). Constructing the iron cage: Institutional theory and enactment. In R. Westwood \& S. Clegg (Eds.), Debating organizatons: Pointcounterpoint in organizational studies (pp. 195-207). Malden, MA: Blackwell.

Kvale, S., \& Brinkmann, S. (2009). Interviews: Learning the craft of qualitative research interviewing (2nd ed.). Thousand Oaks, CA: Sage.

Lawn, M., \& Grek, S. (2012). Europeanizing Education - Governing a new policy space. Oxford: Symposium Books.

Lindgren, J., Hult, A., Segerholm, C., \&Rönnberg, L. (2012). Mediating school inspection Key dimensions and keywords in agency text production 2003-2010. Education Inquiry, 3(4), 569-590.

Lindgren, J. (2015). The front and back stages of Swedish school inspection: Opening the black box of judgment. Scandinavian Journal of Educational Research, 59(1), 58-76.

Manzon, M. (2007). Comparing places. In M. Bray, B. Adamson, \& M. Mason (Eds.), Comparative education research - Approaches and methods (pp. 85-122). The University of Hong Kong, Hong Kong: Springer.

Mediås, O. A. (1996). Skoledirektørembetet i Norge - 1860-1992 [The Office of the School Director in Norway - 1860-1992] [In Norwegian]. Oslo: Ministry of Education, Research and Church Affairs.

Meyer, J. W., \& Rowan, B. (1977). Institutionalized organizations: Formal structure as myth and ceremony. American Journal of Sociology, 83(2), 340-363.

The Norwegian Directorate for Education and Training. (2013). Metodehåndbok for tilsyn en håndbok i metode for tilsyn etter barnehageloven og opplæringsloven [Methods for inspection - a handbook of inspection methods in compliance with the Pre-school Act 
and the Education Act]. Oslo: The Norwegian Directorate for Education and Training. Retrieved from http://www.udir.no/Regelverk/Tilsyn/Metode-for-tilsyn/

Ozga, J. (2012). Governing knowledge: Data, inspection and education policy in Europe. Globalisation, Societies and Education, 10(4), 439-455.

Parsons, T. (2012). (1951) The Social System. New Orleans, LA: Quid Pro.

Pollitt, C., \& Bouckaert, G. (2004). Public management reform: A comparative analysis. Oxford: Oxford University Press.

Power, M. (1997). The audit society - Rituals of verification. Oxford: Oxford University Press.

Ragin, C., \& Amoroso, L. M. (2011). Constructing social research (2nd ed.). Thousand Oaks, CA: Pine Oaks Press/Sage.

Rönnberg, L. (2014). Justifying the need for control. Motives for Swedish national school inspection during two governments. Scandinavian Journal of Educational Research, 58(4), 385-399.

Rönnberg, L. (2011). Exploring the intersection of marketisation and central state control through Swedish national school inspection. Education Inquiry, 2(4), 689-707.

Rönnberg, L., Lindgren, J., \& Segerholm, C. (2013). In the public eye: Swedish school inspection and local newspapers: Exploring the audit-media relationship. Journal of Education Policy, 28(2), 178-197.

Scott, W. R. (2014). Institutions and organizations - Ideas and interests (4th ed.). Thousand Oaks, CA: Sage.

Scott, W. R., \& Meyer, J. W. (1994). Institutional environments and organizations: Structural complexity and individualism (4th ed.). Thousand Oaks, CA: Sage.

Segerholm, C. (2009). "We are doing well on QAE": The case of Sweden. Journal of Education Policy, 24(2), 195-209.

Selznick, P. (1957). Leadership in administration. New York, NY: Harper \& Row.

Silverman, D. (2011). Interpreting qualitative data. London/Los Angeles, CA: Sage.

Sivesind, K. (2012). Juss + ped = sant? Om felles nasjonalt tilsyn i Oslo og Akershus 2008. $[$ Law + Pedagogy $=$ Truth? On regular state inspection in Oslo and Akershus counties 2008]. In H. Jakhelln \& T. Welstad (Eds.), Utdanningsrettslige emner [Legal topics in education] (pp. 655-681). Oslo: Cappelen Damm AS.

Sowada, D. P. M. G., \& Dedering, K. (2014). Ermessensspielräume in der Bewertungsarbeit von Schulinspektor/innen. Zeitschrift für Bildungsforschung,4(2), 119-135. 
Steiner-Khamsi, G. (2002). Re-framing educational borrowing as a policy strategy. In M.

Caruso \& H. E. Tenorth (Eds.), Internationalization - Comparing educational systems and semantics (pp. 57-89). Frankfurt: Peter Lang.

Thornton, P. H., \& Oscasio, W. (2008). Institutional logics. In R. Greenwood et al. (Eds.), The Sage handbook of organizational institutionalism (pp. 99-129). Thousand Oaks, CA: Sage.

Tschannen-Moran, M. (2004). Trust matters: Leadership for successful schools. San Francisco, CA: Jossey-Bass.

Weick, K. E. (1979). The social psychology of organizing. Reading, MA: Addison-Wesley.

Weick, K. E. (2001). Making sense of the organization. Malden, MA: Blackwell.

Weick, K. E. (2009a). Enacting an environment: Infrastructure of organizing. In K. E. Weick (Ed.), Making sense of the organization: The impermanent organization (Vol. II). Chichester: Wiley.

Weick, K. E. (2009b). Making sense of the organization: The impermanent organization (Vol. II). Chichester: Wiley.

de Wolf, I. F., \& Janssens, F. J. G (2007). Effects and Side Effects of Inspections and Accountability in Education: An Overview of Empirical Studies. Oxford Review of Education, 33 (3), 379-396. 